\title{
K-MEANS Clustering Analysis Pada Persebaram Tingkat Pengangguran Kabupaten/Kota Di Sulawesi Selatan
}

\author{
Akramunnisa $^{1}$, Fajriani $^{2}$ \\ 1,2Universitas Cokroaminoto Palopo \\ 1akramunnisa89@gmail.com, ${ }^{2}$ fajrianisyaba@gmail.com \\ DOI 10.30812/varian.v3i2.652
}

\begin{tabular}{|c|c|}
\hline INFO ARTIKEL & ABSTRAK \\
\hline & mengetahui \\
\hline Riwayat Artikel: & kabupaten/kota di Sulawesi Setalan berdasarkan indikator tingkat pengangguran \\
\hline Diterima: $11-03-2$ & dengan menggunakan clustering analysis. Indikator yang digunakan adalah tingkat \\
\hline Disetujui: 04-04-2020 & pengangguran terbuka (TPT), upah minimum kabupaten/kota (UMK) dan laju \\
\hline & $\begin{array}{l}\text { pertumbuhan indeks pembangunan manusia (IPM). Algoritma yang digunakan } \\
\text { dalam metode penelitian ini adalah K-means. Hasil analisis k-means clustering }\end{array}$ \\
\hline Kata Kunci: & $\begin{array}{l}\text { menunjukkan bahwa dari } 24 \text { kabupaten/kota di Sulawesi Selatan terbagi menjadi } \\
\text { dua kelompok, yaitu kelompok tingkat pengangguran tinggi dan rendah. Kelompok }\end{array}$ \\
\hline $\begin{array}{l}\text { Clusterin, K-means, } \\
\text { Tingkat } \\
\text { pengangguran }\end{array}$ & $\begin{array}{l}\text { dengan tingkat pengangguran tinggi terdiri dari } 3 \text { wilayah, yaitu Palopo, Parepare, } \\
\text { dan Makassar. } 21 \text { wilayah yang lain termasuk pada kelompok dengan tingkat } \\
\text { pengangguran rendah. }\end{array}$ \\
\hline
\end{tabular}

\begin{abstract}
This study aims to determine the distribution of districts in South Sulawesi based on unemployment rate indicators using clustering analysis. The indicators are unemployment rate (TPT), districts minimum wage (UMK) and human development index growth rate (IPM). The algorithm used in this study is $\mathrm{k}^{-}$ means clustering. The results of $k$-means clustering analysis showed that of 24 districts in South Sulawesi are divided into two clusters, namely the high and low unemployment rate. The high employment rate cluster consists of 3 districts, namely Palopo, Parepare, and Makassar. The rest, 21 districts are in the low employment rate cluster.
\end{abstract}

\section{A. PENDAHULUAN}

Pengangguran merupakan suatu kondisi dimana seseorang tidak mempunyai pekerjaan (Badan Pusat Statistik Provinsi Sulawesi Selatan 2017). Pengangguran menjadi salah satu bagian dari permasalahan utama dalam negara berkembang. Pengangguran di negara berkembang seperti Indonesia dapat disebabkan oleh beberapa faktor, diantaranya laju pertumbuhan penduduk yang tinggi, ketersediaan lapangan pekerjaan yang tidak berimbang, ketidaksiapan penduduk usia produktif dalam menghadapi pesatnya kemajuan teknologi, tingkat pendidikan, perubahan struktur perekonomian, dan besaran upah (Priastiwi and Handayani 2019). Tingkat pengangguran di Indonesia termasuk pada kategori tinggi, meskipun mengalami penurunan dari tahun 2015 sampai 2019. Tercatat bahwa pada akhir tahun 2019, tingkat pengangguran di Indonesia mencapai 5.28\% (Badan Pusat Statistik 2019). Di Sulawesi Selatan, tingkat pengangguran juga mengalami penuruna, dari 2018 ke 2019, yaitu turun sebesar 0.37\%, akan tetapi masih di atas 5\% (Badan Pusat Statistik Provinsi Sulawesi Selatan 2019). Tinggi rendahnya tingkat pengangguran, berpengaruh terhadap tingkat kemiskinan pada suatu wilayah (Itang 2015). Oleh karena pengangguran 
merupakan salah satu faktor penting terhadap tingkat kemiskinan, maka perlu adanya penelitian lebih mendalam yang berkaitan dengan tingkat pengangguran beserta indikator yang berpengaruh terhadap perubahan tingkat pengangguran. Salah satunya adalah dengan menggunakan metode pengengelompokkan.

Metode pengelompokkan yang sering digunakan dalam penelitian adalah clustering analysis. Clustering analysis merupakan salah satu teknik pengelompokkan untuk analisis pada data mining (Sardar and Ansari 2018). Clustering analysis yang sering dijumpai dalam penelitian adalah clustering analysis menggunakan algoritma k-means. Hal ini disebabkan karena algoritma k-means mampu menghasilkan cluster yang optimum dengan konvergensi yang cepat (Sardar and Ansari 2018),(Kakushadze and Yu 2017). Pengelompokkan dengan menggunaan k-means diterapkan di berbagai bidang, diantaranya adalah kesehatan, pertanian, dan pendidikan. Seperti pengelompokkan tentang hasil pertanian (Bobby Poerwanto and Fa'rifah 2019), pengelompokkan tingkat keganasan kanker (Kakushadze and Yu 2017), penentuan kriteria penerima JAMKESDA (Waworuntu and Amin 2018), pengelompokkan proses registrasi suatu antrian (Zhu et al. 2019), dan untuk pemetaan siswa berprestasi (Sibuea and Sapta 2017).

Berdasarkan uraian di atas, penelitian ini mengelompokkan kabupaten/kota di Sulawesi Selatan berdasarkan indikator-indikator yang berpengaruh terhadap tingkat pengangguran menggunakan k-means clustering analysis. Penelitian yang berkaitan dengan tingkat pengangguran yang pertama adalah pengaruh kepadatan penduduk, PDRB, tingkat pendidikan, tingkat kesehatan, dan UMK terhadap tingkat pengangguran di Jambi. Hasilnya menunjukkan bahwa yang berpengaruh terhadap tingkat pengangguran adalah tingkat kesehatan dan tingkat pendidikan (Harlik, Amir, and Hardiana 2013). Penelitian yang kedua adalah tentang faktor yang berpengaruh terhadap angka pengangguran di Bali. Hasil analisis menunjukkan bahwa UMK dan PDRB berpengaruh terhadap perubahan angka pengangguran di Bali (Sirait and Marhaeni 2005). Penelitian yang ketiga adalah pengelompokkan tingkat pengangguran di Maluku dengan indikator yang digunakan adalah rata-rata jumlah penduduk, rata-rata TPAK, jumlah angkatan kerja, rata-rata penduduk usia 15 tahun ke atas, dan TPT. Penelitian tersebut menghasilkan 3 kelompok, yaitu kelompok dengan tingkat pengangguran tinggi, tingkat pengangguran sedang, dan rendah (Rahakbauw, Sinay, and Enus 2017).

Mengacu pada penelitian yang telah dilakukan sebelumnya, yaitu faktor yang berpengaruh terhadap pengangguran, yaitu variabel tingkat pendidikan, dan tingkat kesehatan, dan UMK (Harlik, Amir, and Hardiana 2013), (Sirait and Marhaeni 2005), maka selain menggunakan TPT sebagai indikator utama, penelitian ini akan menggunakan indikator UMK sebagai salah satu indikator dalam pengelompokkan Indikator yang lain yang lain adalah IPM, yaitu suatu indeks yang diperoleh berdasarkan tingkat pendidikan, tingkat kesehatan, dan perekonomian penduduk. IPM dalam hal ini mewakili tingkat pendidikan, tingkat kesehatan pada penelitian sebelumnya. Hasil yang diperoleh dari pengelompokkan TPT, IPM dan UMK dikategorikan menjadi 2 cluster, yaitu cluster 1 merupakan kelompok dengan tingkat pengangguran rendah dan cluster 2 merupakan tingkat pengangguran tinggi. Hasil analisis yang diperoleh dapat dijadikan sebagai gambaran bagi pemerintah daerah/kota bahkan tingkat provinsi dalam menangani masalah pengangguran dengan melihat aspek yang berpengaruh terhadap perubahan tingkat pengangguran, yaitu UMK dan IPM

\section{B. METODOLOGI}

Penelitian ini menggunakan data sekunder yang berasal dari BPS Sulawesi Selatan. Data tersebut adalah laju pertumbuhan indeks pembangunan manusia (IPM) dalam persen, upah minimum kabupaten/kota (UMK) dalam juta rupiah, serta tingkat pengangguran terbuka (TPT) dalam persen. Data tersebut merupakan data tahun 2014. Ketiga indikator tersebut merupakan variabel yang digunakan dalam proses pengelompokkan kabupaten/kota.

Algoritma k-means dalam clustering analysis merupakan salah satu algoritma yang populer digunakan dalam pengelompokkan (Kakushadze and Yu 2017). K-means juga memberikan kemudahan dalam pengelompokkan, karena penentuan jumlah cluster ditentukan terlebih dahulu sebelum melakukan analisis. 
Algoritma k-means dapat dituliskan sebagai berikut:

1. Input: Data IPM dan UMK

2. Inisial: $K, C_{l j}$

3. Proses:

a. Menghitung jarak Euclidean dengan rumus:

$$
d=\sqrt{\sum_{i=1}^{N} \sum_{j=1}^{J} \sum_{l=1}^{K}\left(X_{i j}-C_{l j}\right)^{2}}
$$

b. Menentukan anggota dari masing-masing cluster berdasarkan hasil perhitungan jarak terdekat.

c. Menghitung centroid dari masing-masing cluster dengan persamaan:

$$
C_{l j}=\frac{1}{n_{l j}}\left(\sum_{i=1}^{N_{l j}} X_{i j}\right)
$$

d. Mengulang kembali proses pada poin a sampai c hingga tidak ada perubahan anggota pada setiap cluster yang terbentuk.

4. Output: Hasil cluster (Kakushadze and Yu 2017), (B Poerwanto and Fa'rifah 2016)

Keterangan:

$K \quad$ : banyak Cluester

$X_{i j}$ : variabel yang digunakan dalam clustering

$C_{l j}:$ centroid dalam cluster

$i \quad$ : indeks jumlah data yang digunakan $(i=1, \ldots, N)$, untuk masing-msing cluster, jumlah data sebanyak $n_{l j}$

$j \quad$ : indeks jumlah variabel yang digunakan dalam clustering $(j=1, \ldots, J)$

$l \quad$ : indeks jumlah centroid, dengan jumlah sesuai banyaknya cluster $(l=1, \ldots, K)$

Dalam penelitian ini jumlah cluster yang digunakan adalah dua cluster, yaitu cluster pertama adalah tingkat pengangguran rendah pengangguran rendah adalah kabupaten/kota di bawah Sedangkan tingkat adalah rata-rata TPT TPT Sulawesi Selatan. Jumlah sebanyak 24, sesuai dengan yang ada di Sulawesi Selatan. dapat dilihat pada diagram

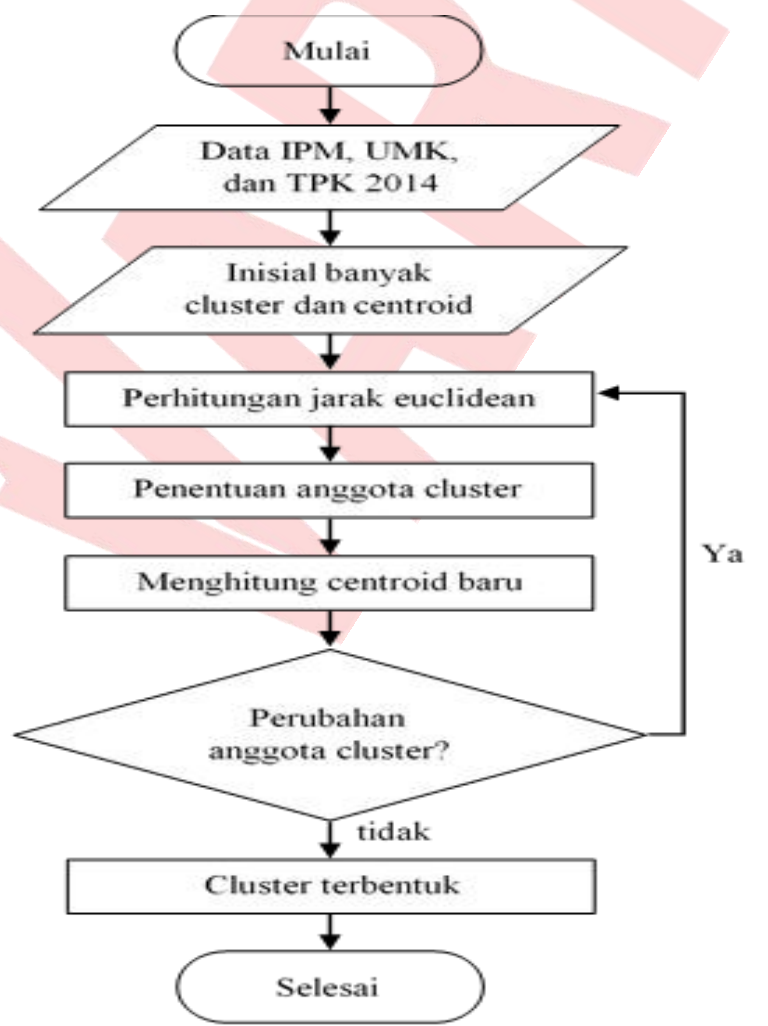
dan tinggi. Tingkat rata-rata TPT TPT Sulawesi Selatan. pengangguran tinggi kabupaten/kota di atas data yang digunakan jumlah kabupaten/kota Tahapan penelitian ini berikut. 
Gambar 1. Diagram Alir K-Means Clustering

\section{HASIL DAN PEMBAHASAN}

Visualisasi TPT kabupaten/kota di Sulawesi Selatan dapat dilihat pada gambar 2 di bawah ini.

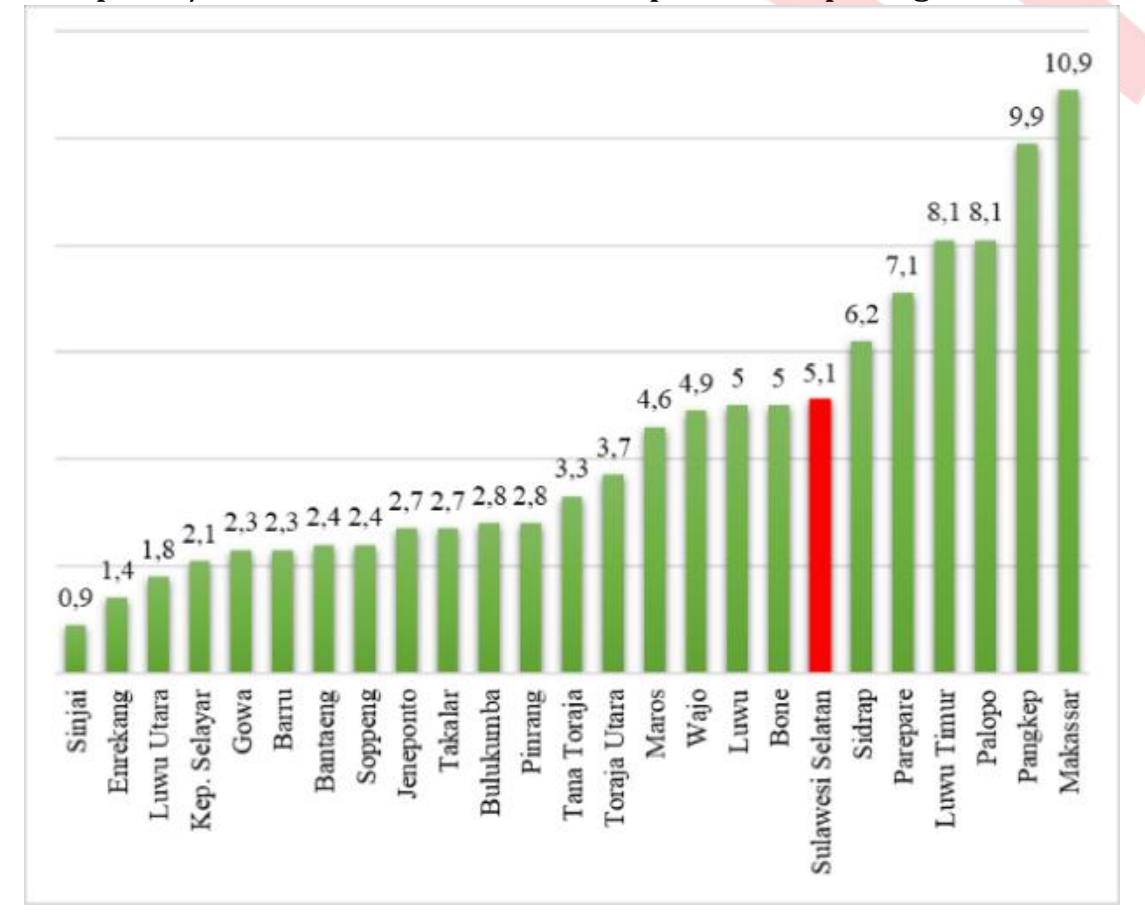

Gambar 2. TPT Kabupaten/Kota di Sulawesi Selatan Tahun 2014 (\%)

Berdasarkan gambar di atas, diperoleh informasi bahwa TPT Kabupaten Sinjai adalah yang paling rendah, yaitu sebesar $0.9 \%$. sedangkan yang paling tinggi adalah Kota Makassar, yaitu mencapai $10.9 \%$. Selain Kota Makassar, terdapat 5 kabupaten/kota dengan TPT lebih tinggi dari TPT Sulawesi Selatan, yaitu Kabupaten Sidrap, Kota Parepare, Kabupaten Luwu Timur, Kota Palopo, dan Kabupaten Pangkep. Diketahui bahwa yang mendominasi lapangan usaha di Sulawesi Selatan adalah sektor pertanian, yaitu sebesar 41.8\%, dilanjutkan 19.9\% disektor jasa, 19.1\% pada sector perdagangan/hotel/rumah makan, sektor industri pengolahan sebesar 5.7\%, dan sisanya sebesar 13.5\% adalah bergerak dibidang sektor listrik, gas, air, bangunan/konstruksi, penggalian, angkutan, komunikasi dan lembaga keuangan (Badan Pusat Statistik 
Provinsi Sulawesi Selatan 2014a). Hal ini sangat memungkinkan Makassar penghasil TPT tertinggi karena lahan pertanian di Makassar sangat kurang, sedangkan lapangan usaha sektor yang lain tidak mencapai $20 \%$.

Gambaran untuk indikator tingkat pengangguran dapat dilihat pada gambar 3 dan gambar 4 berikut.

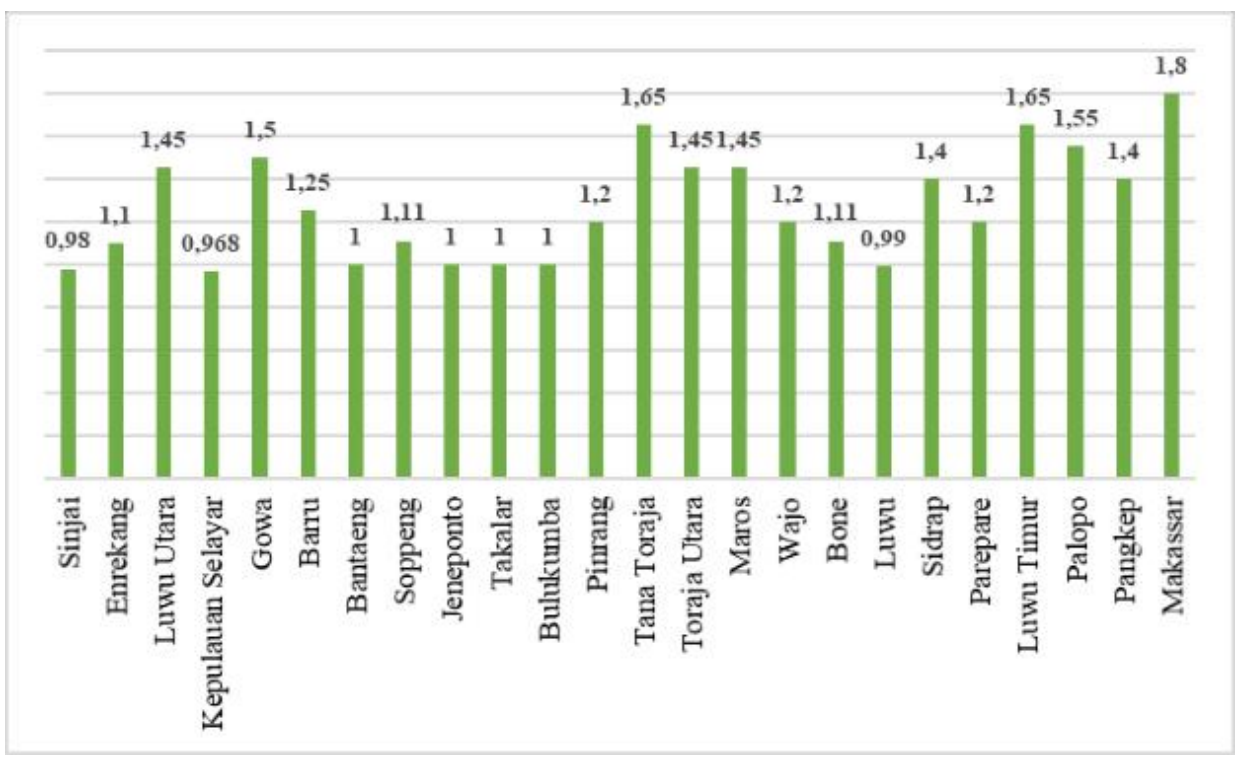

Gambar 3. UMK Kabupaten/Kota di Sulawesi Selatan Tahun 2014 (Juta rupiah)

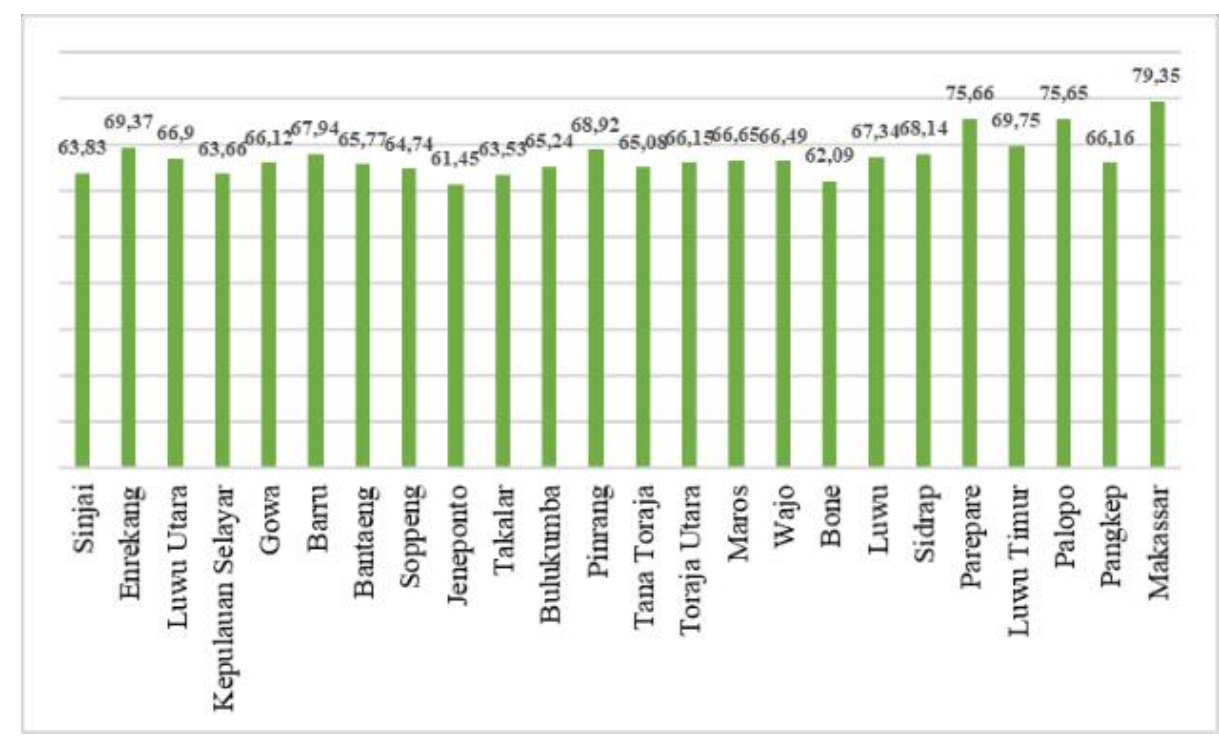

Gambar 4. IPM Kabupaten/Kota di Sulawesi Selatan Tahun 2014 (\%)

Berdasarkan gambar 3 dan gambar 4, diketahui bahwa UMK dan IPM tertinggi di Sulawesi Selatan adalah Makassar, yaitu sebesar 1.8 juta rupiah untuk UMK dan 79.35\% untuk IPM. Makassar merupakan ibu kota provinsi dengan jumlah penduduk terpadat, yaitu 1.4 juta jiwa. Penduduk di Sulawesi Selatan didominasi oleh kelompok usia produktif, yaitu usia 15 sampai 40 tahun (Badan Pusat Statistik Provinsi Sulawesi Selatan 2014b). Sedangkan untuk UMK terendah adalah Kepulauan Selayar dan IPM terendah di Kabupaten Jeneponto.

Clustering analysis dengan menggunakan algoritma k-means dimulai dengan menentukan banyaknya cluster dan inisial centroid secara random untuk iterasi pertama. Dengan menggunakan 2 cluster, centroid awal yang diperoleh secara random adalah sebagai berikut:

Tabel 1. Pemilihan Centroid Awal 
1

\begin{tabular}{lrr}
\hline UMK & 1.11 & 1.8 \\
IPM & 62.09 & 79.35 \\
TPT & 5 & 10.9 \\
\hline
\end{tabular}

Centroid awal yang terpilih adalah Kabupaten Bone untuk cluster 1 dengan UMK sebesar 1.11 juta rupiah, IPM 62.09\%, dan TPT 5\%, sedangkan untuk cluster 2 adalah Kota Makassar dengan UMK sebesar 1.8 juta rupiah, IPM 79.35\%, dan TPT sebesar 10.9\%. Setelah centroid terpilih, tahap berikutnya adalah menghitung jarak antara indikator masing-masing kabupaten/kota dan centroid terpilih dengan menggunakan rumus jarak Euclidean. Berikutnya menentukan anggota cluster berdasarkan jarak terdekat yang diperoleh. Selanjutnya adalah menghitung centroid baru berdasarkan hasil cluster yang terbentuk. Tahapan ini dilakukan sebanyak beberapa kali iterasi sampai hasil yang diperoleh tidak terdapat perubahan anggota kelompok yang ditandai dengan tidak ada selisis centroid antara iterasi tertentu dengan sebelumnya. Hasil iterasi pada k-means clustering analysis penelitian ini adalah:

Tabel 2. Hasil Iterasi K-means Clustering Analysis

\begin{tabular}{rcc}
\hline \multirow{2}{*}{ Iterasi } & \multicolumn{2}{c}{ Perubahan Nilai Centroid } \\
\cline { 2 - 3 } & 1 & 2 \\
\hline 1 & 3.912 & 2.486 \\
2 & 0.178 & 0.622 \\
3 & 0.008 & 0.135 \\
4 & 0.000 & 0.009 \\
5 & 0.000 & 0.000 \\
6 & 0.000 & 0.000 \\
\hline
\end{tabular}

Iterasi dalam memperoleh hasil cluster yang optimum pada penelitian ini adalah sebanyak 6 kali. Perubahan nilai centroid adalah selisih dari centroid pada iterasi tertentu dengan centroid sebelumnya. Jika perubahan centroid menunjukkan angka 0 , maka tidak ada perubahan pada centroid dari sebelumnya dengan centroid tertentu, seperti pada iterasi kelima dan keenam. Centroid tidak mengalami perubahan, sehingga keanggotaan cluster juga tidak berubah. Iterasi yang dihasilkan masih di bawah 10, hal ini menunjukkan clustering algoritma k-means dapat menghasilkan cluster dengan cepat. Hal ini sejalan dengan hasil pengelompokkan penyakit kanker, yang memperoleh anggota cluster lebih cepat dari metode hierarchical clustering (Kakushadze and Yu 2017). K-means clustering juga memberikan hasil yang lebih optimal dibandingkan dengan fuzzy c-means clustering analysis dalam mengelompokkan kecamatan di Tana Luwu berdasarkan hasil perkebunan (Bobby Poerwanto and Ali 2019). Hasil clustering dengan algoritma k-means juga memberikan hasil yang lebih optimum dan efisien dari algoritma lain pada proses pengelompokkan data cloud computing (Jiang et al. 2020). Iterasi kelima dan keenam menghasilkan anggota cluster 1 terdiri dari 18 wilayah dan cluster 2 ada 3 wilayah. Cluster 1 merupakan kelompok tingkat pengangguran rendah, dan cluster 2 adalah kelompok tingkat pengangguran tinggi. Pada cluster 2 anggotanya adalah Kota Makassar, Kota Parepare, dan Kota Palopo. Ketiga wilayah ini merupakan tiga kota besar di Sulawesi Selatan dengan rata-rata tingkat pengangguran di atas Sulawesi Selatan, yaitu 8.7\%.

Jumlah cluster pada algoritma k-means ini sudah pasti, namun keanggotaan dalam cluster yang masih belum jelas. Keanggotaan didasarkan pada kemiripan karakteristik dari indikator yang digunakan. Berbeda dengan hierarchical clustering analysis, jumlah cluster dan banyak anggota diketahui setelah melakukan tahapan analisis. Hasil pengelompokkan dengan menggunakan angoritma k-means lebih optimum bila dibandingkan dengan algoritma-algoritma dalam hierarchical clustering (Govender and Sivakumar 2020). Kelompok pada masing-masing cluster dapat dilihat pada tabel 3 berikut ini. 
Tabel 3. Hasil Pengelompokkan K-means Clustering

\begin{tabular}{rlrr}
\hline No & \multicolumn{1}{c}{ Kabupaten/ Kota } & Cluster & Jarak \\
\hline 1 & Sinjai & 1 & 3.517 \\
2 & Enrekang & 1 & 4.099 \\
3 & Luwu Utara & 1 & 2.110 \\
4 & Kepulauan Selayar & 1 & 2.810 \\
5 & Gowa & 1 & 1.414 \\
6 & Barru & 1 & 2.408 \\
7 & Bantaeng & 1 & 1.318 \\
8 & Soppeng & 1 & 1.779 \\
9 & Jeneponto & 1 & 4.629 \\
10 & Takalar & 1 & 2.638 \\
11 & Bulukumba & 1 & 1.167 \\
12 & Pinrang & 1 & 3.081 \\
13 & Tana Toraja & 1 & 1.050 \\
14 & Toraja Utara & 1 & .280 \\
15 & Maros & 1 & 1.164 \\
16 & Wajo & 1 & 1.327 \\
17 & Bone & 1 & 4.098 \\
18 & Luwu & 1 & 1.920 \\
19 & Sindereng Rappang & 1 & 3.330 \\
20 & Parepare & 1 & 2.042 \\
21 & Luwu Timur & 1 & 5.825 \\
22 & Palopo & 1.376 \\
23 & Pangkep & 1 & 6.236 \\
24 & Makassar & 1 & 3.314 \\
\hline
\end{tabular}

Tabel 3 menunjukkan tentang persebaran kabupaten/kota yang terbagi ke dalam dua cluster. Cluster 1 memiliki anggota sebanyak 21 kabupaten/kota yang merupakan kelompok tingkat pengangguran rendah (rata-rata TPT kabupaten/kota lebih rendah dari TPT Sulawesi Selatan) dan Cluster 2 adalah kelompok untuk kabupaten/kota dengan tingkat pengangguran tinggi (rata-rata TPT kabupaten/kota lebih tinggi dari TPT Sulawesi Selatan) dengan anggota sebanyak 3 wilayah. Kabupaten/kota yang termasuk pada cluster 1 adalah Kepulauan Selayar, Bulukumba, bantaeng, Jeneponto, Takalar, Gowa, Sinjai Maros, Barru, Bone, Soppeng, Wajo, Pinrang, Enrekang, Luwu, Tana toraja, Luwu Utara, Toraja Utara, Pangkep, Sidrap, dan Luwu Timur. Sedangkan untuk cluster 2 adalah Parepare, Makassar, dan Palopo. Jarak cluster dapat dilihat pada tabel 4 berikut.

Tabel 4. Jarak antar Cluster yang terbentuk

\begin{tabular}{llccc}
\hline Cluster & & $\mathbf{1}$ & $\mathbf{2}$ & \\
\hline & 1 & & 12.021 \\
& 2 & 12.021 & \\
\hline
\end{tabular}

Tingkat pengangguran dari kabupaten/kota dari masing-masing cluster dapat dilihat pada tabel 5 dan tabel 6 berikut ini.

Tabel 5.TPT Kabupaten/Kota dalam Cluster 1

\begin{tabular}{lr}
\hline Kabupaten/ Kota & TPT \\
\hline Sinjai & 0.9 \\
Enrekang & 1.4 \\
Luwu Utara & 1.8 \\
Kep. Selayar & 2.1 \\
Gowa & 2.3 \\
Barru & 2.3
\end{tabular}




\begin{tabular}{lr}
\hline Kabupaten/ Kota & TPT \\
\hline Bantaeng & 2.4 \\
Soppeng & 2.4 \\
Jeneponto & 2.7 \\
Takalar & 2.7 \\
Bulukumba & 2.8 \\
Pinrang & 2.8 \\
Tana Toraja & 3.3 \\
Toraja Utara & 3.7 \\
Maros & 4.6 \\
Wajo & 4.9 \\
Luwu & 5 \\
Bone & 5 \\
Sidrap & 6.2 \\
Luwu Timur & 8.1 \\
Pangkep & 9.9 \\
\hline
\end{tabular}

Tabel 6.TPT Kabupaten/Kota dalam Cluster 2

\begin{tabular}{lr}
\hline Kabupaten/ Kota & TPT \\
\hline Parepare & 7.1 \\
Palopo & 8.1 \\
Makassar & 10.9 \\
\hline
\end{tabular}

Hasil di atas memperlihatkan keanggotaan kabupaten/kota pada masing-masing cluster. Cluster 1 memiliki persentase tingkat pengangguran terendah adalah $0.9 \%$ yaitu Kabupaten Sinjai dengan rata-rata TPT dari semua anggota adalah 3.68\%. Persentase tersebut di bawah TPT Sulawesi Selatan yang sebesar 5.1\%. Sedangkan pada cluster 2 yang paling rendah adalah kota Parepare (7.1\%) dan paling tinggi adalah Kota Makassar (10.9\%). Rata-rata TPT dari ketiga wilayah ini adalah sebesar 8.7\%, 3.6\% lebih tinggi dari Sulawesi Selatan. Hasil k-means clustering analysis tingkat pengangguran dengan menggukana indikator UMK, IPM, dan TPT menunjukkan kemiripan dengan visualisai TPT kabupaten/kota pada gambar 2, meskipun terdapat 3 wilayah yang tidak termasuk di dalamnya, yaitu Sidrap, Pangkep, dan Luwu Timur.

Hasil penelitian ini dapat digunakan untuk mengetahui bagaimana kondisi penduduk kabupaten/kota di Sulawesi Selatan berdasarkan tingkat pengangguran. Hasil penelitian ini juga dapat digunakan sebagai acuan pada pemerintah daerah, kota, maupun provinsi dalam upaya mengurangi tingkat pengangguran dengan memperhatikan indikator-indikator penyebab perubahan tingkat pengangguran.

\section{SIMPULAN DAN SARAN}

Berdasarkan hasil penelitian dan pembahasan yang telah dikemukakan pada bab sebelumnya, diperoleh bahwa dengan menggunakan k-means clustering analysis 24 kabupaten/kota di Sulawesi Selatan tersebar ke dalam 2 cluster, yaitu cluster dengan rata-rata tingkat pengangguran rendah dan tinggi. Kabupaten/kota yang termasuk pada tingkat pengangguran tinggi ada sebanyak 3 wilayah, yaitu Palopo, Parepare, dan Makassar. Kategori tingkat pengangguran rendah ada 21 wilayah, diantaranya Kepulauan Selayar, Bulukumba, Bantaeng, Jeneponto, Takalar, Gowa, Sinjai, Maros, Barru, Pinrang, Enrekang, Soppeng, Bone, Wajo, Luwu, Tana Toraja, Luwu Utara, Toraja Utara, Pangkep, Sidrap, dan Luwu Timur. 
Penelitian ini dapat dikembangkan dengan menambahkan indikator yang mempengaruhi tingkat pengangguran pada wilayah lain sesuai dengan penelitian yang relevan. K-means clustering analysis ini dapat diterapkan pada berbagai studi kasus, seperti penelitian-penelitian terdahulu (Sardar and Ansari 2018), (Kakushadze and Yu 2017), (Bobby Poerwanto and Fa'rifah 2019), (Waworuntu and Amin 2018), (Govender and Sivakumar 2020), karena cakupan algoritma k-means sangat luas. K-means ini tidak hanya dapat diterapkan pada data berskala interval dan rasio, tetapi pada data kategori berskala ordinal juga dapat diterapkan. Oleh karena itu, disarankan untuk dapat memanfaatkan k-means clustering analysis untuk cakupan studi kasus yang lebih luas.

\section{E. UCAPAN TERIMA KASIH}

Peneliti mengucapkan banyak terima kasih kepada Universitas Cokroaminoto Palopo yang telah memberikan dukungan moral maupun material melalui hibah internal penelitian dosen pemula berbasis luaran, sehingga penelitian ini dapat terlaksana dengan baik.

\section{REFERENSI}

Badan Pusat Statistik. 2019. Berita Resmi Statistik Keadaan Ketenagakerjaan Indonesia Agustus 2019. Jakarta.

Badan Pusat Statistik Provinsi Sulawesi Selatan. 2014a. Berita Resmi Statisti Keadaan Ketenagakerjaan Sulawesi Selatan Agustus 2014. Makassar.

-_- 2014b. Statistik Sosial Dan Ekonomi Rumah Tangga Sulawesi Selatan 2014. Makassar.

-_- 2017. Berita Resmi Statistik Keadaan Ketenagakerjaan Sulawesi Selatan Agustus 2017. Makassar.

_-_. 2019. 63 Berita Resmi Statistik Keadaan Ketenagakerjaan Sulawesi Selatan 2019. Makassar.

Govender, P, and V Sivakumar. 2020. “Application of K-Means and Hierarchical Clustering Techniques for Analysis of Air Pollution: A Review ( 1980 - 2019 )." Atmospheric Pollution Research 11: 40-56.

Harlik, Amri Amir, and Hardiana. 2013. "Faktor-Faktor Yang Mempengaruhi Kemiskinan Dan Pengangguran Di Kota Jambi." Jurnal Perspektif Pembiayaan dan Pembangunan Daerah 1(2): 109-20.

Itang. 2015. "Faktor Faktor Penyebab Kemiskinan.” Tazkiya, Jurnal Keislaman, kemasyarakatan \& kebudayaan 16(1): 1-30.

Jiang, Zoe L et al. 2020. "Efficient Two-Party Privacy-Preserving Collaborative k -Means Clustering Protocol Supporting Both Storage and Computation Outsourcing." Information Sciences 518: 168-80.

Kakushadze, Zura, and Willie Yu. 2017. "K-Means and Cluster Models for Cancer Signatures.” Biomolecular Detection and Qu antification 13: 7-31.

Poerwanto, B, and R Y Fa'rifah. 2016. "Analisis Cluster K-Means Dalam Pengelompokkan Kemampuan Mahasiswa." Indonesian Journal of Fundamental Sciences 2(2): 92-96.

Poerwanto, Bobby, and Baso Ali. 2019. "Implementasi Algoritma Fuzzy C-Means Dalam Mengelompokkan Kecamatan Di Tana Luwu Berdasarkan Produktifitas Hasil Perkebunan.” 
Jurnal MATRIK 19(1): 163-72.

Poerwanto, Bobby, and Riska Yanu Fa'rifah. 2019. “Algoritma K-Means Dalam Mengelompokkan Kecamatan Di Tana Luwu Berdasarkan Hasil Produktifitas Hasil Pertanian." Jurnal Ilmiah d'COMPUTARE 9(1): 46-51.

Priastiwi, Dian, and Herniawati Retno Handayani. 2019. “Analisis Pengaruh Jumlah Penduduk, Pendidikan, Upah Minimum, Dan PDRB Terhadap Tingkat Pengangguran Terbuka Di Provinsi Sulawesi Selatan." Diponegoro Journal of Economics 1(1): 159-69.

Rahakbauw, Dorteus L, Lexy J Sinay, and Vilomina Enus. 2017. “Aplikasi Metode Fuzzy C-Means Untuk Menentukan Tingkat Pengangguran." Jurnal Ilmu Matematika dan Terapan 11(2): 95100.

Sardar, Tanvir Habib, and Zahid Ansari. 2018. "An Analysis of MapReduce Efficiency in Document Clustering Using Parallel K-Means Algorithm." Future Computing and Informatics Journal xx: 110.

Sibuea, Fitri Larasati, and Andy Sapta. 2017. "Pemetaan Siswa Berprestasi Menggunakan Metode KMeans Clustering." JURTEKSI, Jurnal Teknologi dan Sistem Informasi IV(1): 85-92.

Sirait, Novlin, and A. A. I. N. Marhaeni. 2005. "Analisis Beberapa Faktor Yang Berpengaruh Terhadap Jumlah Pengangguran Kabupaten / Kota Di Provinsi Bali." Jurnal Ekonomi Pembangunan Universitas Udayana 2(2): 108-18.

Waworuntu, M. Nanda Variestha, and Muhammad Faisal Amin. 2018. "Penerapan Metode K-Means Pemetaan Calon Penerima JAMKESDA." KLIK, Kumpulan Jurnal Ilmu Komputer 05(02): 190200.

Zhu, Jihua et al. 2019. "Efficient Registration of Multi-View Point Sets by K-Means Clustering." Information Sciences 488: 205-18. 